\title{
South African petitions to the House of Commons, 1833-1914: Grievances, protests, advice and information
}

\section{A. J. Christopher*}

\begin{abstract}
Petitioning includes the right of individuals directly to request the sovereign or parliament to redress grievances, heed protests, receive advice and consider relevant information, thereby circumventing intermediaries. Thus in the period 1833-1914, although most South African petitions were addressed to the local authorities, some were sent directly to the House of Commons in London, as the ultimate effective apex of the imperial governmental system. Most petitions were concerned with personal grievances against the government, while others were concerned with political advocacy in the form of protest or advice, including substantial supporting information. Only three political issues attracted wider action within the settler society, amounting to concerted campaigns. These were the introduction of representative government in the Cape of Good Hope; opposition to the settlement of transported criminals from the United Kingdom; and support for the maintenance of the established status of the Church of England. From the 1880s, petitions by indigenous Africans raised protests at political developments that affected them negatively, notably political exclusion from parliament. However, the scale of South African petitioning was small and essentially marginal to political discourse in London.
\end{abstract}

Keywords: South Africa; British Empire; petitions; parliament; constitutional change; church governance.

\section{Opsomming}

Petisionering sluit die reg in van die indiwidu om op direkte wyse die heerser of parlement te versoek om griewe aan te spreek en reg te stel, om op proteste ag te slaan, en om advies te ontvang en relevante inligting in ag te neem. Só word daar rondom die tussenpersoon of bemiddelaar gewerk. Alhoewel die meeste SuidAfrikaanse petisies in die tydperk 1833-1914 aan die plaaslike owerhede geadresseer is, is sommige petisies wel direk na die House of Commons in Londen,

* Anthony Christopher is professor emeritus of Geography in the Department of Geosciences, Nelson Mandela University, Port Elizabeth. The financial assistance of the National Research Foundation towards the costs of this research is hereby acknowledged. The opinions expressed in this article and the conclusions arrived at are not necessarily to be attributed to the National Research Foundation.

How to cite this article: A.J. Christopher, "South African petitions to the House of Commons, 18331914: Grievances, protests, advice and information”, Historia, 63, 1, May 2018, pp 1-23. http://dx.doi.org/10.17159/2309-8392/2018/v63n1a1

Copyright: (CThe Author(s). Published under a Creative Commons Attribution Licence. 
effektief die toppunt van die imperiale regeringstelsel, gestuur. Die meeste petisies het te make gehad met persoonlike griewe teen die regering, terwyl ander petisies politieke aanbevelings gemaak het in die vorm van protes of advies, volledig met substantiewe inligting wat dit onderskraag het. Slegs drie politieke kwessies het tot 'n breër optrede, in die vorm van doelgerigte veldtogte, in die setlaar samelewing gelei. Dit was, onderskeidelik, die begin van verteenwoordigende regering in die Kaap van Goeie Hoop, teenstand teen die hervestiging van kriminele uit die Verenigde Koninkryk, en ondersteuning vir die handhawing van die gevestigde status van die Church of England. Petisies van Afrikane het sedert die 1880's protes aangeteken teen kwessies wat hulle negatief beïnvloed het, mees vernaamlik hul politieke uitsluiting uit die parlement. Die omvang van Suid-Afrikaanse petisionering was egter klein en marginaal tot die politieke diskoers in Londen.

Sleutelwoorde: Suid-Afrika; Britse Ryk; petisies; parlement; konstitusionele verandering; kerkbestuur.

\section{Introduction}

Petitions are requests for the redress of grievances or offers of advice concerning the resolution of personal and political issues of importance that are presented in writing to a person or authority with the power to alleviate the injustice or pursue a different course of action. ${ }^{1}$ In general they are sent from those ruled to their rulers, humbly requesting their aid in righting perceived wrongs, and supplying information thought necessary to support the request, thereby providing the authorities with a useful source of intelligence independent of that sent by the state bureaucracy. The right has been exercised in many societies over a long period of time under a variety of forms and names. ${ }^{2}$ In the European form, petitions were usually addressed to the king or ruler, but could also be presented to lower orders of administration possessing a more immediate means of securing justice or carrying out the desired changes. They also included pleas from those who were disenfranchised, notably women, who sought to bring their plights or concerns to the attention of the authorities for redress. $^{3}$ Some petitions were highly localised and less formally phrased and structured raising specific issues of tenant/landowner and employer/employee

1. L. Heerma van Voss, "Petitions in Social History: Introduction", International Review of Social History, 46, 9 (2001), pp 1-10.

2. A. Würgler, "'Voices from among the 'silent masses': Humble Petitions and Social Conflicts in early Modern Central Europe”, International Review of Social History, 46, 9 (2001), pp 11-34; B. Kumin and A. Würgler, "Petitions, Gravamina and the early Modern State: Local Influence on Central Legislation in England and Germany (Hesse)", Parliaments, Estates and Representation, 17 (1997), pp 36-60.

3. M.S. Blaine, "The Power of Petitions: Women and the New Hampshire Provincial Governments, 1695-1770", International Review of Social History, 46, 9 (2001), pp 57-77; S. Zaeske, "Signatures of Citizenship: The Rhetoric of Women's Antislavery Petitions", Quarterly Journal of Speech, 88, 2 (2002), pp 147-168. 
relations, which were not subject to official oversight. ${ }^{4}$ However, many of those recorded were concerned with gaining direct access to rulers or state councils and parliaments, thereby appealing to the central authority and perceived source of state power rather than to intermediaries. This was particularly noticeable in peripheral or colonial communities whose inhabitants sought to draw their specific problems to the attention of distant governments, which petitioners considered might lack sufficient information to be able to appraise the situation. ${ }^{5}$ In time, petition writing was widely adopted by disenfranchised colonial peoples, as a means of appealing to the authorities for the redress of grievances and raise issues of political advocacy and protest. 6

In the nineteenth and early twentieth centuries a new society evolved in South Africa as a result of European overseas settlement within an expanding British Empire. ${ }^{7}$ Although faced with different concerns from those faced by the United Kingdom, many of the English constitutional practices were retained by emergent colonial societies. At the same time, the authorities sought to incorporate African indigenous peoples into the imperial system by instilling a common British identity, owing allegiance to the monarch, thereby aligning African traditional leadership with

4. R.A. Houston, Peasant Petitions: Social Relations and Economic Life on Landed Estates (Palgrave Macmillan, Basingstoke, 2014), pp 73-107; G. Kynoch, "'Your petitions are in mortal terror': The Violent World of Chinese Mineworkers in South Africa, 19041910", Journal of Southern African Studies, 31, 3 (2005), pp 531-546; K. Lunn and A. Day, "Deference and Defiance: The Changing Nature of Petitioning in British Naval Dockyards", International Review of Social History, 46, 9 (2001), pp 131-150.

5. N. Corbett, "Parliamentary Petitions: An Untapped Library Resource", Australian Library Journal, 60, 3 (2011), pp 218-230; K. Ellingford, “The Purpose, Practice and Effects of Petitioning the Victorian Parliament", Australasian Parliamentary Review, 23, 2 (2008), pp 86-112; J.K. Johnson, “'Claims of equity and justice': Petitions and Petitioners in Upper Canada, 1815-1840", Histoire Sociale/Social History, 28, 55 (1995), pp 219-240; J.R. Robertson, Petitions of the early Inhabitants of Kentucky to the General Assembly of Virginia 1769 to 1792 (Genealogical Publishing, Baltimore: MD, 1998); J. Vernet, "Petitions from the Peripheries of Empire: Louisiana and Quebec", American Review of Canadian Studies, 38, 4 (2008), pp 495-512; D. Zaret, Origins of Democratic Culture: Printing, Petitions and the Public Sphere in Early-Modern England (Princeton University Press, Princeton: NJ, 2000), pp 231-240.

6. S. Abraham, "Formal Writing, Questionnaires and Petitions: Colonial Governance and Law in early Colonial Malabar 1792-1810", Indian Historical Review, 40, 2 (2013), pp 285-305; K.O. Akurang-Parry, '“A smattering of education' and Petitions as Sources: A Study of African Slaveholders' Responses to Abolition in the Gold Coast Colony, 18741875", History in Africa, 37 (2000), pp 39-60; L. Kapteijns and J. Spaulding, "Women of the Zar and Middle-class Sensibilities in Colonial Aden, 1923-1932", Sudanic Africa, 5 (1994), pp 7-38; C.J. Korieh, “'May it please your Honor': Letters of Petition as Historical Evidence in a Colonial Context", History in Africa, 37 (2010), pp 83-106; P. Swarnalatha, "Revolt, Testimony, Petition: Artisanal Protests in Colonial Andhra", International Review of Social History, 46, 9 (2001), pp 107-129.

7. A. Lester, Imperial Identities: Creating Identities in Nineteenth Century South Africa and Britain (Routledge, London, 2001), pp 176-192. 
British hierarchical patterns. ${ }^{8}$ Expressions of loyalty to the Crown also helped to counter white settler prejudices and exclusivity. ${ }^{9}$ The resultant dual identity of South African nationals, themselves of diverse origins, and their parallel status as British subjects was described perceptively by the minister of the interior, Dr D.F. Malan, in 1927 as: "every South African national is, and must be, a British subject. South African nationality is merely a smaller circle within a larger one". 10 The functioning of the British Empire has been represented as a series of networks, webs and circuits linking the various parts, peoples and institutions together. ${ }^{11}$ Within this network "the centrality of London" as the focus of power, patronage, finance and communication was a vital link. ${ }^{12}$ In this paper it is proposed to examine one of the strands in this web of empire, linking one peripheral society to the centre. This was composed of the flow of information contained in the series of petitions from South Africa to the House of Commons in Westminster, between the reform of parliament in the 1830s and the First World War. The article begins with an overview of the petitioning process and the place of colonial petitions within the overall scheme of the House of Commons. There follows a chronological review of the petitions received from South Africa, marking the changes in the concerns raised. A conclusion seeks to draw the threads together.

\section{Petitioning the House of Commons}

The right of anyone, whether male or female, enfranchised or not, to approach the sovereign or parliament directly for the redress of grievances or for a solution of their problems is one of the basic rights enshrined in the common law of England and the various countries whose legal systems are derived from it. ${ }^{13}$ In the reign of Edward I (1272-1307) parliament gained a major role in the solicitation, reception and processing of petitions drawn-up according to set rules and procedures. They could be concerned with matters of both national and local concern and provided valuable

8. C.V. Reed, Royal Tourists, Colonial Subjects and the Making of a British World, 18601911 (Manchester University Press, Manchester, 2016), pp 191-196.

9. A. Thompson, "The Languages of Loyalism in South Africa c1870-1939", English History Review, 118, 477 (2003), pp 617-650.

10. Union of South Africa, Debates of the House of Assembly, Volume 9, col. 3996, (Malan), 23 May 1927.

11. A. Lester, "Imperial Circuits and Networks: Geographies of the British Empire", History Compass, 4, 1 (2006), pp 124-141.

12. Z. Laidlaw, Colonial Connections, 1815-45: Patronage, the Information Revolution and Colonial Government (Manchester University Press, Manchester, 2005), pp 17-21; G.B. Magee and A.S. Thompson, Empire and Globalisation: Networks of People, Goods and Capital in the British World, c1850-1914 (Cambridge University Press, Cambridge, 2010).

13. D. Hirst, "Making Contact: Petitions and the English Republic", Journal of British Studies, 45, 1 (2006), pp 26-50; R. Hough, "Do Legislative Petition Systems Enhance the Relationship between Parliament and Citizen?" Journal of Legislative Systems, 18, 3-4 (2012), pp 479-495; D. Judge, "Public Petitions and the House of Commons", Parliamentary Affairs, 31, 4 (1978), pp 391-405. 
sources of information for the king and parliament on matters of public policy. ${ }^{14}$ Subsequently, the scope of parliamentary petitions expanded as the administration received advice and protests. ${ }^{15}$ It is significant that parliament received petitions from the peripheral parts of the king's dominions, then including Scotland, Ireland and Gascony. Nevertheless, petitions were received and dealt with by the local authorities with appeals to the king as a last recourse. ${ }^{16}$ Petitioning was incorporated into the laws and usages of the colonies and states which evolved as a result of English and British colonial activity. Thus the American Continental Congress petitioned the king for redress in the period before the declaration of independence. ${ }^{17}$ Similarly, the West Indian parliaments and colonists' interest groups sent petitions to parliament favouring the retention of slavery in the late eighteenth and early nineteenth centuries. ${ }^{18}$ However, most petitions concerning the colonies originated in the United Kingdom, notably during the controversies surrounding the abolition of the slave trade and slavery. ${ }^{19}$ Thus between 1824 and 1833 some 20000 petitions were received in favour of the abolition of slavery in the colonies. ${ }^{20}$ In 1833 alone a total of 5020 petitions with 1.3 million signatures originated within the United Kingdom, calling for the abolition of slavery. ${ }^{21}$ Although the right was clearly stated, colonial subjects exercised this approach comparatively rarely with regard to the distant imperial parliament in London because most grievances involved the local administration and therefore might be more readily dealt with locally. An approach to the authorities in London was essentially a last resort when all other avenues of redress had been exhausted and the petitioners considered a final appeal to those perceived to possess the power to overcome local obstacles.

The handling of petitions by parliament was reorganised and streamlined between 1833 and 1842 as part of the general political transformation associated

14. P. Brand, "Petitions and Parliament in the Reign of Edward I", Parliamentary History, 23, 1 (2004), pp 14-38.

15. G. Dodd, Justice and Grace: Private Petitioning and the English Parliament in the late Middle Ages (Oxford University Press, Oxford, 2007), pp 317-325.

16. G. Pepin, "Petitions from Gascony: Testimonies of a Special Relationship", in W.M. Ormrod, G. Dodd and A Musson (eds), Medieval Petitions: Grace and Grievance (York Medieval Press, Woodbridge, 2007), pp 120-134.

17. E. Wolf, "The Authorship of the 1774 Address to the King Restudied", William and Mary Quarterly, 22, 2 (1965), pp 189-224.

18. D. Lambert, "The Counter-revolutionary Atlantic: White West Indian Petitions and the Proslavery Networks", Social and Cultural Geography, 6, 3 (2005), pp 405-420.

19. S. Drescher, "Public Opinion and Parliament in the Abolition of the British Slave Trade", Parliamentary History, 26, 1 (2007), pp 42-65; S. Drescher, Capitalism and Antislavery: British Mobilization in Comparative Perspective (Oxford University Press, Oxford, 1984), pp 92-93.

20. R. Handley, "Public Order, Petitioning and Freedom of Assembly", Journal of Legal History, 2 (1986), pp 123-155, statistic at p140.

21. Parliamentary Archives, Westminster, London (hereafter PA), HC/CL/JO/6/170 and 171 Session 1833, Reports of the Select Committee on Public Petitions 1833. 
with the Great Reform Act of $1832 . .^{22}$ Petitions were presented to the House of Commons by a member, although it should be noted that the presentation did not necessarily mean approval by the member responsible, nor could debate then be entered into over its merits. The petition was then referred to the permanent Select Committee on Public Petitions for consideration. ${ }^{23}$ It was then subjected to scrutiny to see that it was drawn up in the prescribed manner; that the subject was within the ambit of parliamentary oversight; and to determine what action needed to be taken. Notably, requests for direct financial assistance were not entertained. The historic form and humble wording of petitions often recalled the prayers of the Church for divine intervention in human affairs. ${ }^{24}$

Petitions were required to be drawn up in three sections and "should be specifically and respectfully addressed to the House of Commons". 25 The first section came with the humble request to the honourable House for redress, identifying the petitioners, followed by a statement of the problem facing the petitioners, including previous attempts to secure satisfaction, and finally a proposed course of action to alleviate or solve the problem had to be clearly laid out. The persons addressing the House had to state their names and sign or make their mark on the petition, or if submitted by a corporate entity, the entity's seal might be attached. After the reforms in 1833, printed lists of the petitions were published and indexed by the name of the first petitioner or corporate body under five broad subject headings (Parliament, Ecclesiastical, Colonies, Taxes, Miscellaneous) and then listed by individual topic for the parliamentary record of the committee's meetings. ${ }^{26}$ In addition the full texts of some were printed as numbered appendices, although where they differed comparatively little from others already published, they were not printed but were indicated as being similar to the one previously printed. (During many of the major petitioning campaigns local meetings often used the wording of an existing petition.) In this process of compression, nearly all the names of the petitioners and dates were lost and editorial amendments were made ensuring a degree of standardisation in the printed record. These sets of documents represent the surviving record because most of the original petitions were then destroyed as a space saving exercise. ${ }^{27}$

22. P. Fraser, "Public Petitioning and Parliament before 1832", History, 46, 158 (1961), pp 195-211; J.E. Bradley, "Parliament, Print Culture and Petitioning in late Eighteenth Century England", Parliamentary History, 26, 1 (2007), pp 218-230.

23. PA, Book/1248, B.J. Enright, Reports of the Committee on Public Petitions in the House of Commons Library, 1960.

24. D. Nicholls, "Addressing God as Ruler: Prayer and Petition", British Journal of Sociology, 44, 1 (1993), pp 125-141.

25. M. Jack, Erskine May's Treatise on the Law, Privileges, Proceedings and Usage of Parliament (LexisNexis, London, 2011), p 482.

26. $\mathrm{PA}, \mathrm{HC} / \mathrm{CL} / \mathrm{JO} / 6$, Record series includes the reports of the Select Committee on Public Petitions and the appendices for the period covered. The appendices were usually published in separate volumes.

27. $\mathrm{PA}, \mathrm{HL} / \mathrm{PO} / 6$, Record series contains some original nineteenth-century petitions which for various reasons were not destroyed. 
The volume of petitions presented to the House of Commons between 1833 and 1914 was considerable, with nearly a million in the period of 82 years under consideration (see Table 1). The flow was highly erratic with marked peaks and troughs. Thus in the two peak years of 1843 and 1893, some 33898 and 33742 petitions respectively were presented bearing 6.1 and 5.0 million signatures respectively. It has been observed that:

At a time when petitioning has been reduced to an anachronism with no significant role in public affairs it is easy to overlook its importance in popular politics in the 1840s. During the Chartist years petitioning was arguably the most common form of political activity in Britain in this era, reaching its apex with the massive petitions organized by the Chartists. ${ }^{28}$

Peaks were balanced by years with fewer than 10000 petitions in the preceding five years on both occasions. As the parliamentary correspondent for The Times noted in 1901, it was only "those prepared as a result of widespread concerted action", which gained attention. He further commented that: "the belief in the efficacy of individual appeals to Parliament has not yet entirely died out ... but if the man in the street could see how unceremoniously the ordinary memorial is dealt with this belief would not long survive". ${ }^{29}$ It was a measure of the widening of the franchise that there was a general decline in petitioning, as the actions of organised political parties assumed greater significance in the late nineteenth and early twentieth centuries, thereby affording the means of concerted action required to effect changes. ${ }^{30}$

Table 1: Petitions presented to the House of Commons 1833-1914

\begin{tabular}{llll}
\hline Years & $\begin{array}{l}\text { Total number of } \\
\text { petitions }\end{array}$ & $\begin{array}{l}\text { Number of colonial } \\
\text { petitions }\end{array}$ & $\begin{array}{l}\text { Number of South } \\
\text { African petitions }\end{array}$ \\
\hline $1833-42$ & 108407 & 332 & 6 \\
$1843-52$ & 144203 & 227 & 35 \\
$1853-62$ & 114763 & 221 & 6 \\
$1863-72$ & 157728 & 2128 & 16 \\
$1873-82$ & 165272 & 245 & 4 \\
$1883-92$ & 124034 & 993 & 1 \\
$1893-1902$ & 92487 & 1040 & 1 \\
$1903-14$ & 53227 & 74 & 9 \\
\hline Total & 960121 & 5260 & 78 \\
\hline
\end{tabular}

Source: Reports of the Select Committee on Public Petitions, 1833-1914.

28. P.A. Pickering, “'And Your Petitioners \&c': Chartist Petitioning in Popular Politics, 1838-48”, English Historical Review, 116, 466 (2001), pp 368-388, quotation at p 369.

29. The Times, Our Parliamentary Correspondent, "Petitions to the House of Commons", 7 September 1901, p 4.

30. C. Leys, "Petitioning in the 19th and 20th centuries", Political Studies, 3,1 (1955), pp 479-495. 
Only $0.5 \%$ of petitions in the period covered originated in the colonies and of these only $1.5 \%$ originated in South Africa, compared with $4.2 \%$ in Australia and New Zealand, 5.6\% in Canada and $84.2 \%$ in India. ${ }^{31}$ The educated Indian elite found petitioning a direct and effective means of raising grievances and promoting political programmes and protests in a peaceful manner. In addition, petitions offered the government a valuable source of information on the state of Indian society, the problems it encountered and the deficiencies of the colonial responses. ${ }^{32}$ Furthermore, in societies with low levels of literacy, before the introduction of universal education in the late nineteenth and twentieth centuries, scribes, clerks, lawyers and letter-writers were available to record, translate and attest for people unable to do so themselves. Thus petitioning was open to literate and illiterate alike, whether in thirteenth century England or nineteenth and twentieth-century South Africa and India. Thus the scale of colonial petitioning also reflected the size of the population, which in 1911 had reached 315.2 million in India compared with only 6.0 million in South Africa. ${ }^{33}$ In making these identifications there is some ambiguity as the number of petitions concerning colonial affairs was far higher. There were petitions from businessmen with interests in various colonies, retired colonial civil, naval and army officers as well as lawyers representing colonial interests, who were resident in the United Kingdom and have been excluded from the calculations. ${ }^{34}$ On occasion residents of the colonies petitioned parliament while they were visiting England, and these petitions, where they are clearly identifiable, have been included in the colonial totals.

A third of the petitions (27) originating from South Africa were presented in the two years 1850 and 1851. These were concerned with the question of a new constitution for the Cape of Good Hope and the introduction of representative government, and also with the introduction of transported convicts. Political developments were otherwise rare subjects because the main complaints concerned personal grievances against the local authorities, where no satisfaction could be obtained by the petitioners. The right to petition was maintained as part of the inalienable heritage of being a British subject, wherever, he or she might reside. This

31. PA, HC/CL/JO/658, Session 1890, App. 30, p 15. The Indian Council's Amendment Bill attracted 748 petitions with 394946 signatures in favour; 3 petitions with 45896 signatures against; and 1 petition with 22 signatures for an amendment to be presented to parliament in the 1890 session. Such a scale of external petitioning of the imperial parliament was unique outside India.

32. M. Siddiqi, The British Historical Context and Petitioning in Colonial India (Aakar Books, New Delhi, 2005), pp 17-37.

33. Great Britain, Census of England and Wales 1911, General Report, Cd8491 (H.M.S.O., London, 1917), p 286.

34. For example: PA, HC/CL/JO/6/197, Session 1839, App. 447, p 224. Petition from "merchants and others interested in the prosperity and civilization of Southern Africa", requesting foundation of Natal; and PA, HC/CL/JO/6/865, Session 1906, App. 17, $\mathrm{p}$ 17, Petition from "Alfred Mangena, a member of the Zulu race presently residing in England; and a law student of Lincoln's Inn for an Imperial Government enquiry into the Native Rising in Natal". 
was expressed in the preamble to a petition from the inhabitants of Cape Town in 1842:

That the inhabitants of this colony, being descended from the people of Holland or British born subjects who have more recently settled here, since becoming an integral portion of the British Empire, entertain an hereditary sentiment of veneration for the free institutions of the distinguished nations from which they sprang. ${ }^{35}$

\section{South African petitions, 1833-1838}

The first petition from South Africa in the period, however, was of a different sentiment; it related to the abolition of slavery debates and was drawn up by 3540 "Proprietors and Managers of Slaves in the Cape of Good Hope, and these at present constitute a large portion of the wealth and property of your Petitioners". They objected to the Order-in-Council of 1831 issued for the improvement of slave conditions:

... bearing upon the face thereof the stamp of utter ignorance of the condition of Slavery in, and of the general state of this Colony, but moreover introducing a series of most harassing and vexatious duties upon the Masters, exposing them to a cruel system of oppression, subjecting them to a number of ruinous penalties without almost the power of escape ... to destroy all value of slave property ... to drive your Petitioners to ruin and despair. ${ }^{36}$

The solution proposed was the introduction of a legislative assembly for the Cape Colony, which would draw up its own laws and regulations, free of interference from the London authorities. Such a loosening of imperial links was in marked contrast to a petition in 1875 when some 22937 members of the Poona Sarvajanik Sabha and other inhabitants of the Bombay presidency which called for the direct election of representatives of India in the imperial parliament in order to overcome a lack of local knowledge in the House of Commons. ${ }^{37}$

It is scarcely surprising that the petitions were often lengthy with extensive historical backgrounds to the problems and arguments presented, rather than the more usual brief supportive or negative comments on pending legislation which dominated petitions originating in the United Kingdom. As an example, the second South African petition in the period, presented in 1835, began as follows:

Petition of the undersigned resident Colonists of the District of Albany, in the Colony of the Cape of Good Hope, now in London.

Humbly sheweth,

That your honourable House, in the Session of the year 1819, acceded to a grant of $£ 50,000$ for the purpose of sending out settlers to colonize a division of the Colony of the Cape of Good Hope.

35. PA, HC/CL/JO/6/218, Session 1842, App. 721, p 268.

36. PA, HC/CL/JO/6/171, Session 1833, App. 1271, p 1369.

37. PA, HC/CL/JO/6/497, Session 1875, App. 324, p 157. 
That your Petitioners, with their families, and near five thousand other British subjects, accepted the proposals made to them by His Majesty's Ministers, and early in the next year embarked for that Colony, ignorant of their actual destination, but relying on the faith and protection of the British Government.

That on their arrival in Table Bay, they were informed that they were to be located on the Eastern frontiers, six hundred miles from the seat of Government, within the ancient boundaries of the Colony, but in a district which some of the Caffre tribes had encroached upon, and from whence they had the year before been expelled by the military.

That, for some time, the new Settlement enjoyed peace and security, but ...38

There follows an account of subsequent events, until the final part of the petition outlines the redress sought:

They therefore pray that your honourable House will take their unfortunate case into consideration, and order such measures to be taken as may be thought expedient for their future protection.

A similar petition followed, requesting redress for the destruction of property suffered due to warfare. ${ }^{39}$ Two years later, another protested about the

... continuance of these unrelenting miseries, that at length no less than from 2,000 to 3,000 of their hardiest peasantry, the best defenders of the frontier have been forced to emigrate from this Country, wearied out by the incessant outrages to which they have been exposed. 40

This was supported the following year by a further petition, which was directed to be printed in the House of Commons Journal. ${ }^{41}$ A motion to investigate the plight of the Albany settlers was subsequently defeated. ${ }^{42}$ No further mention was made of the issue in petitions to the House. Indeed, in the first nine years of the period under consideration only five petitions originated from South Africa.

\section{Constitutional change and transportation, 1842-1854}

There followed the major period of parliamentary petition writing, covering an era of significant constitutional change. In this it coincided with a peak in petitioning in the United Kingdom with a petition by the Chartists in 1848 securing a purported 5.7 million signatures, although many of these were duplicate or fraudulent. In South

38. $\mathrm{PA}, \mathrm{HC} / \mathrm{CL} / \mathrm{JO} / 6 / 178$, Session 1835, App. 1335, p 980. Original spelling retained.

39. PA, HC/CL/JO/6/178, Session 1835, App. 1512, p 1131.

40. PA. HC/CL/JO/6/187, Session 1837, App. 925, p 457.

41. Journals of the House of Commons, Volume 93, Session 1837-8, p 615, 15 June 1838.

42. Hansard, Series 3, Volume 44, Session 1837-8, cols 114-117. (Gladstone, Grey, division), 10 July 1838. The motion was rejected by 32 votes for and 41 against, in a House of Commons with 658 members, on the basis that the issues raised in had already been investigated. The low participation rate reflected the lateness of the vote, after midnight, towards the end of the daily order paper, to where most colonial matters were relegated. 
Africa, parallel moves for constitutional reform took place. ${ }^{43}$ These dealt mainly with the need for representative government and attempts to boost the image of the colony. Thus in 1842, a petition from the inhabitants of Cape Town and vicinity linked the two, showing:

That at the present period they think it unnecessary to offer any argument in favour of that form of government of which Her Majesty is the head, or to point out the inevitable disadvantages under which a government must labour which possesses no constitutional means of ascertaining public opinion, or to show that a people thus excluded from all influences on the action of government must advance slowly, if at all, in the career of improvement: these facts have been decided by the concurrent testimony of all ages. They think it enough to represent that in numbers, wealth, and intelligence, they consider this community fully prepared to take their place in the ranks of free countries, being assured that Her Majesty only waited for such an assurance before confiding in them their due weight in the legislature of their own country. ${ }^{44}$

In 1848 the movement became more active. A petition was drawn up and signed by 80 inhabitants of the Koeberg area in the Cape District in 1848, and was followed by two more from the inhabitants of Stellenbosch (22 signatures) and combined Cape and Stellenbosch districts (58 signatures). The Koeberg petition noted the extension of self-government to the colonies, but the tardiness of its introduction at the Cape and desired that it be implemented "more promptly". ${ }^{45}$ In 1850 the petitioning took on a more concerted nature, with more specific demands. In 1851 a precise constitution of 16 articles was presented by Cape Town petitioners, to overcome flaws perceived in the proposed official provisions, which had "entirely lost the confidence of Her Majesty's faithful people".46 Two articles concerning eligibility to vote and to stand for election are particularly intriguing, representing a demand for a colour-blind franchise and membership:

Art 5. Every male inhabitant of the full age of 21 years, who shall have occupied fixed property for his own use and benefit of the value of $£ 25$, for 12 calendar months next preceding the registration and time of voting within the limits of an electoral division shall be entitled to vote for members of Assembly to represent that division, and for members of Council.

Art 6. Every male inhabitant entitled to vote for members of Assembly shall be eligible for election to a seat in the House of Assembly; and every male inhabitant of the age of 30 years who shall have resided in the colony during 3 years preceding the registration and time of voting, and who shall be the proprietor of landed property situate within the colony of the value of not less than $£ 1000$ shall be eligible for election to a seat in the Legislative Council.

43. J.L. McCracken, The Cape Parliament, 1854-1910 (Clarendon Press, Oxford, 1967) pp 1-17.

44. PA, HC/CL/JO/6/218, Session 1842, App. 721, p 368.

45. PA, HC/CL/JO/6/264, Session 1847-8, App. 1052, p 552. Note that there was a threemonth delay between the date of the document (10 March 1848) and its presentation to parliament (2 June 1848).

46. PA, HC/CL/JO/6/287, Session 1851, App. 53, p 23. 
It was supported by petitions from other parts of the colony. ${ }^{47}$ The tardiness of the government in introducing representative government resulted in the presentation of further petitions to spur the imperial government into the implementation of reform, together with more general observations on the state of the eastern frontier and colonial finances. ${ }^{48}$ Petitions continued to reach London until 1853, when the necessary constitutional changes were effected. ${ }^{49}$ The creation of an elected local House of Assembly provided an alternative outlet for colonial petitioners to express their grievances and influence government policies. Once elected in 1854, the Cape of Good Hope House of Assembly duly received over a hundred petitions per year on average in its first decade of existence. These covered a wide variety of personal and local grievances, suggestions for improvements and political comment, particularly upon bills under consideration by the assembly. ${ }^{50}$

Entangled with the constitutional issue was that of the future character of colonial society, notably the question of the transportation of convicts from the United Kingdom to penal colonies. The proposal to use the Cape of Good Hope for this purpose met marked resistance as inhibiting the future development of the colony, and was characterised as a "struggle [that] has created a people of South Africa". ${ }^{1}$ In 1848 the Municipality of Cape Town drew up a petition, presented to parliament the following year, noting:

That Her Majesty's Government contemplate transporting to this colony persons convicted of political and other crimes or offences, for the purpose, amongst others, of supplying any deficiency of labour which may exist in this colony, have humbly and most dutifully represented to Her Majesty the injustice of converting this colony into a penal settlement, and the danger of exposing the multitudes of semi-barbarous tribes it contains to the evil influences of such persons, and beseeching, for the reasons set forth in the Petition to Her Majesty, that the measure may not be carried out. ${ }^{52}$

Further petitions were sent the following year by the Municipality of Cape Town as a result of public meetings held by the inhabitants. ${ }^{53}$ In 1850 this was supported by the inhabitants of Port Elizabeth, requesting the House to "pass an Act whereby the Cape Colony shall be declared now and for ever Free, a Colony which

47. PA, HC/CL/JO/6/286, Session 1851, Petitions p 749.

48. PA, HC/CL/JO/6/294, Session 1852, App. 7, p 6.

49. PA, HC/CL/JO/6/303, Session 1852-3, App. 248, p 122.

50. Cape of Good Hope, Votes and Proceedings of the House of Assembly, 1854-1910. The number of petitions received in Cape Town averaged approximately 100 per year until the early 1880s, thereafter the number rose to reach a peak of 623 in 1898, before declining to an annual average of 336 petitions between 1902 and 1909.

51. A.F. Hattersley, The Convict Crisis and Growth of Unity: Resistance to Transportation in South Africa and Australia 1848-1853 (University of Natal Press, Pietermaritzburg, 1865), p 80.

52. PA, HC/CL/JO/6/272, Session 1849, App. 242, p 128.

53. PA, HC/CL/JO/6/280, Session 1850, Apps 1 and 2, p 3. 
neither by an Order in Council nor by any exercise of the Royal Prerogative can ever be made a Penal Settlement". ${ }^{54}$ Similar petitions were sent by the inhabitants of 15 other towns, making the writing campaign the largest in the period under review. ${ }^{55}$ Support for the campaign also came from the inhabitants of Port Philip in Australia, where the extension of transportation to Victoria was equally resisted and the repeal of the Order-in-Council applicable to both colonies was requested. ${ }^{56}$

Another strand of discontent was raised by discussions over the removal of the seat of government from the western to the eastern province. The commissioners of the Municipality of Cape Town drew up a petition in 1851 refuting official allegations of "the determined and dogged inactivity of the farmers, especially the Dutch", noting that "the proceedings of the colonists in general, and of the farmers in particular; as evincing the most unquestionable loyalty to Her Majesty's person and throne, which the most arbitrary and despotic measures could not alienate or impair", and further stating:

In the opinion of your petitioners, such removal of the seat of government would be injudicious, attended with enormous expense, be an act of gross injustice, and an unwarrantable assumption on the part of the colonial secretary to dispose of the question of the deepest interest of the inhabitants at large without consulting them in the matter. ${ }^{57}$

It gave an extensive list of reasons not to move and suggested that the issue be left for the future Cape parliament to decide.

The British government's decision to abandon the Orange River Sovereignty in 1854 drew condemnation from meetings of the inhabitants of Colesberg, as being "intimately acquainted with the condition and character and the several requirements of the various classes of Her Majesty's subjects both here and in this colony, whose future welfare would be seriously compromised by the withdrawal of Her Majesty's authority from that settlement", who then petitioned parliament.58 It was noted that wool exports and imports of manufactured goods were rising rapidly, while the administration had brought order, investment and prosperity to the area, which would be severely compromised by the withdrawal. Public petitions from the inhabitants of Cape Town and Port Elizabeth were also sent to the House protesting at the abandonment of the Orange River Sovereignty. ${ }^{59}$ In consequence of the abandonment aggrieved parties petitioned the House of Commons for redress of their losses. These included three land surveyors who had surveyed farms in connection with the issue of title deeds and received no recompense from the new government. ${ }^{60}$

54. PA, HC/CL/JO/6/279, Session 1850, Report, $\mathrm{p} 3$.

55. PA, HC/CL/JO/6/279, Session 1850, Report, p 1602.

56. PA, HC/CL/JO/6/280, Session 1850, App. 1406, p 652.

57. PA, HC/CL/JO/6/287, Session 1851, App. 1356, p 655.

58. PA, HC/CL/JO/6/310, Session 1854, App. 41, p 19.

59. PA, HC/CL/JO/6/310, Session 1854, App. 961, p 426 (Cape Town) and App. 962, p 428 (Port Elizabeth).

60. PA, HC/CL/JO/6/310, Session 1854, App. 1547, p 723. 
The former civil commissioner of Smithfield also approached the House for redress two years later. ${ }^{61}$

\section{Occasional petitions, 1855-1866}

After the activity of a period of constitutional change the number of petitions sent to London fell significantly. The new Cape and Natal constitutions incorporated the right of petition to the colonial parliaments and this became an intermediate recourse for aggrieved persons. However, some still pursued the option of petitioning the imperial parliament, where no satisfaction could be found in Cape Town or Pietermaritzburg. Proposals for the incorporation of British Kaffraria in the Cape Colony in the early 1860 s as an economy measure produced negative reactions locally. In 1863 a petition from 1024 inhabitants of the colony was drawn up for presentation to parliament noting that the removal of the executive government, including a resident lieutenantgovernor, judge, attorney-general and "necessary officers for administering a government", would "seriously retard the prosperity of this colony, and involve the whole of the South African Colonies at no remote period in another disastrous and expensive Kafir war".62 The petitioners requested that the separate status of the colony be maintained. Two years later the warning was repeated noting that "the seat of government of the Cape Colony being too removed from the frontier to effectively guard and watch over the native affairs, which at a distance of 700 miles would become complicated and lead to disastrous results".63 Two years later another petition against the withdrawal troops from the frontier requested "Her Majesty's Government to extend the protection of Her forces to the colonists as they have hitherto enjoyed it". ${ }^{64}$ The petition was rejected by the colonial secretary in view of the financial burden of stationing troops in the colony and problems of local support. 65

In other cases, personal problems, which were ignored by the local governments, did reach London after procrastination in South Africa. Thus the plight of the military settlers, widows and orphaned children of the murdered men of the villages of Auckland, Ely, Johannesberg and Woburn in the Victoria East district were presented to parliament in 1864, some sixteen years after the chain of events commenced. It is indicative of the scope of the petitions, that those with comparatively little education, and no access to the franchise could approach parliament directly, as the spelling in a section of this account attests:

That your Pertitioners* beg to state that the survivers* served throughout the Kaffir war 1846 and 7 as soldiers, and in 1850-1 and 2, in accordance with the tenure contained in general order No. 129, as military settlers, receiving the rate of pay established, and upon which they held their land, in the full expectation of returning to it at the termination of hostilities; but to their great greif* they ware*

61. PA, HC/CL/JO/6/326, Session 1856, Report, p 964.

62. PA, HC/CL/JO/6/393, Session 1863, App. 797, p 377.

63. PA, HC/CL/JO/6/408, Session 1865, App. 582, p 274.

64. PA, HC/CL/JO/6/426, Session 1867, App. 681, p 238.

65. Hansard, Series 3, Volume 188, cols 5-15 (Manchester, Kimberley), 18 June 1867. 
barberously* prohibeted* from doing so by the civil commissioner of the district of Victoria East, and without any authority explaining in writing for what cause they ware* despossed*; and here they themselves, wives, and children, had to seek a living where it could best be obtained. 66

\section{Ecclesiastical petitions, 1867-8}

In 1867 twelve petitions from South Africa were presented to the imperial parliament. The subject of eleven of them involved ecclesiastical matters, which in the United Kingdom exercised the minds of many petitioners, who could be organised and coordinated through the local church structures of parishes and congregations on matters ranging from church disestablishment to temperance and even the population census. ${ }^{67}$ In this case petitions were concerned with the controversy surrounding the case of the Bishop of Natal, John Colenso, following the attempt by the Archbishop of Cape Town to depose him for heresy. This action had brought the legal status of colonial bishops into question and prompted the summoning of the first Lambeth Conference of Anglican diocesan bishops from around the world by the Archbishop of Canterbury in 1867, to which Dr Colenso was not invited. The relationship between the Church in England and Anglican churches elsewhere came under scrutiny as the overseas dioceses gained greater independence and authority. ${ }^{6}$ A petition from Cape Town expressed a general concern:

Your Petitioners humbly pray that no measures may receive the sanction of your honourable House which shall be calculated to interfere with the existing status of the Church of England in the colonies as being an integral part of the Church of England. ${ }^{9}$

The confusion is illustrated by the variety of issues expressed in the petitions. The clergy of Cape Town requested certainty for the legal position and the applicability of English statute law in South Africa. ${ }^{70}$ A petition from Port Elizabeth raised the question of the legitimacy of colonial bishops and their appointment. ${ }^{71} \mathrm{~A}$ petition from the laity of Uitenhage was concerned with the maintenance of the church supremacy of the queen. ${ }^{72}$ The proposal to consecrate a rival bishop in Natal incurred the displeasure of the imperial government, which instructed the colonial government to attempt to prevent such an event. This prompted a detailed, legal

66. PA, HC/CL/JO/6/401, Session 1864, App. 28, p 15. Original footnote: *sic.

67. P.M.H. Bell, Disestablishment in Ireland and Wales (S.P.C.K., London, 1969), p 246; A.J. Christopher, "The Religious Question in the United Kingdom Census, 1801-2011", Journal of Ecclesiastical History, 65, 3 (2014), pp 601-619; J. Greenaway, Drink and British Politics since 1830: A Study in Policy Making (Palgrave Macmillan, Basingstoke, 2003) pp 29-52.

68. E. Matthew, "Law and Religion in South Africa: An Anglican Perspective", Dutch Reformed Theological Journal, 54, 4 (2013), pp 64-73.

69. PA, HC/CL/JO/6/426, Session 1867, App. 54, p 24.

70. PA, HC/CL/JO/6/426, Session 1867, App. 243, p 109.

71. PA, HC/CL/JO/6/426, Session 1867, App. 180, p 84.

72. PA, HC/CL/JO/6/426, Session 1867, App. 289, p 119. 
petition from the Durban advocate, Savery Pinsent to reject such government interference in ecclesiastical affairs as a matter of principle. ${ }^{73}$

\section{Occasional petitions 1879-1914}

There followed ten years with no petitions to the honourable House. Even the outbreak of war in Zululand in 1879 elicited no reaction from South Africa, although 120 petitions on the subject originated in the United Kingdom condemning the war. ${ }^{74}$ However, three petitions from the Cape Colony in that year dealt with the alteration of tariffs on alcohol imported into the United Kingdom. That from the Chamber of Commerce of Cape Town explained the problem and sought changes:

That in consequence of the alteration in the tariff and the introduction of the Alcoholic Test, the wines of this colony are virtually excluded from the English market, because although naturally strong in body experience has proved that a certain amount of spirits is required in addition to the natural strength to fortify the same during so long a voyage, as across the tropics, and in consequence it is found impractical to send Cape wines to the home market. ${ }^{75}$

Political changes in South Africa were occasionally brought to the attention of the House by residents, usually as a matter of seeking redress of personal and wider grievances. Thus in 1881 the "Loyal Inhabitants of the Transvaal" petitioned for compensation for losses incurred in the retrocession of the Transvaal, after the pledges of governors and governments, including successive British prime ministers:

That however unwilling your Petitioners are to believe the mother country to be capable of wilfully and deliberately abandoning her loyal children, who have trusted in her, they are reluctantly compelled to declare themselves cruelly deceived and betrayed, and although nothing can compensate for the breaking up of homes and the loss of friends and relatives who have sacrificed their lives uselessly. ${ }^{76}$

In the 1880s the beginning of increased political activism on the part of the indigenous African population was evident. Petitioning formed part of this activity, although much was addressed to the monarch and her representatives, rather than the unsympathetic white settler controlled local elected bodies, ${ }^{77}$ still nominally subject to imperial oversight. This reflected the emphasis placed upon the monarchy

73. PA, HC/CL/JO/6/434, Session 1867-8, App. 666, p 312.

74. PA, HC/CL/JO/6/533, Session 1879, Report, p 789.

75. PA, HC/CL/JO/6/534, Session 1879, App. 262, p 137.

76. PA, HC/CL/JO/6/555, Session 1881, App. 403, p 189.

77. L. Kuper, "African Nationalism in South Africa, 1910-1964", in M. Wilson and L.M. Thompson (eds), The Oxford History of South Africa, II, South Africa 1870-1966 (Clarendon Press, Oxford, 1971), pp 424-476. 
as the focus of personal and group loyalty in contemporary imperial rhetoric. ${ }^{78}$ In 1885, in a rare direct approach to the House of Commons, the "Native Residents of the Tembu Location District of Glen Grey, South Africa" sought the reversal of the annexation of the Transkeian territories by the Cape Colony in a petition of marked brevity:

That your Petitioners have heard with deep regret of the Resolution passed by the Colonial Government in the House of Assembly, re. The annexation of the Transkeian territories to the Colony.

All the Kaffir races of this country wish to be transferred from this Colonial Government to the Imperial Government, and they were sorry to hear that no retrocession of Transkeian territories was to take place.

That your Petitioners think that the Colonial Government has no right to annex the Transkeian territories and they now appeal to your honourable House. ${ }^{79}$

The late nineteenth and early twentieth centuries represented a significant era in the development of southern Africa. Colonial affairs impacted upon the workings of parliament to a greater extent than before, as evidenced by an increased flow of colonial petitions. Yet little of this flow emanated from South Africa. Indeed, the 1890s passed without a single petition originating in South Africa. However, in 1901 John X. Merriman and Jacobus W. Sauer, political leaders in the Cape colonial legislature petitioned the House of Commons against the developments in South Africa and were particularly concerned about the future constitutional dispensation:

That your Petitioners have heard with great concern that it is the intention of His Majesty's Government to constitute, in the territories recently known as the Orange Free State and the South African Republic, Crown Colony Government. They would venture most respectfully to submit that this form of government, following as it does upon republican institutions, will tend to repel the inhabitants, and that they will in the humble opinion of your Petitioners, judging from past experience, lead to great friction and much future trouble the result of which will most grievously affect your Petitioners and those whom they represent. 80

In 1906 five petitions were sent by various organisations representing the African and coloured populations of the Cape Colony condemning the proposed franchise clauses in the new constitutions of the Orange River Colony and the Transvaal as discriminating against people of colour. That of the Coloured Peoples Vigilance Committee noted that in contrast to the colour-blind constitution of the Cape Colony:

That your Petitioners now learn in fear that it is proposed to grant a constitution to the Transvaal and Orange River Colonies which embody opposite principles to

78. T. Karis and G.M. Carter (eds), From Protest to Challenge: A Documentary History of African Politics in South Africa, 1882-1964, Volume 1, Protest and Hope, 1882-1934 (Hoover Institution Press, Stanford: CA, 1972), pp 3-12.

79. PA, HC/CL/JO/6/596, Session 1885, App. 5, p 3.

80. PA, HC/CL/JO/6/797, Session 1901, App. 27, p 17-18. 
those stated above and exposing all His Majesty's coloured subjects to the injury and degradation of being excluded for the sole reason of colour from any participation in any electoral franchise, local or general.

For all the foregoing reasons your Petitioners hope that your Honourable House will withhold consent to the granting of any constitution to any part of South African wherein all coloured men are excluded from the exercise of the franchise. ${ }^{81}$

The other four petitions were assessed to be of a similar nature and only the earliest received was printed as an annexure to the Select Committee report. However, three more were reproduced in the journal, The Aborigines' Friend. ${ }^{82}$ They included the lengthy legal and historical exposition by Dr Abdullah Abdurahman, the Cape Town city councillor, and the shorter plea from John Tengo Jabavu, the editor of the newspaper Imvo, in their political organisational capacities, indicating that the range of writings sent to parliament was wider than the surviving official record might suggest.

The Zulu rising in Natal in 1906, following the imposition of a $£ 1$ poll tax, did result in petitions on behalf of Tilonko, the Embo chief, who had been imprisoned for ten years on Saint Helena for his alleged role in the murder of a Natal police officer and trooper in Byrnetown. He maintained that this was a miscarriage of justice as a result of the unlawful retrospective application of martial law regulations. As a result: "incursions into Native Reserves led to wanton damage", whereupon: "they stood up to resist, not because they were traitors, but rather because they were Zulus and because they were men". ${ }^{83}$ A similar petition was sent the following year. ${ }^{84}$ The matter was referred back to the prime minister of Natal, and no further action was taken, as the matter was deemed to fall within the competency of the colonial government. ${ }^{85}$

In 1909 two petitions reached the House objecting to aspects of the proposed South African constitution. The first, from the representatives of "five coloured and native congresses", sought to warn the House of the potential alienation of the majority of the population of the country as a result of constitutional exclusion from the political process:

That the status of the coloured people and the natives will be lowered, and that an injustice will be done to those who are the majority of the people in British South Africa, who in the past have shown their unswerving loyalty to the Crown, their attachment to British institutions, their submission to the laws of the land; and their capacity for exercising full civil and political rights. ${ }^{86}$

81. PA, HC/CL/JO/6/865, Session 1906, App. 52, p 35.

82. "Petitions from South Africa", The Aborigines' Friend: Journal of the Aborigines' Protection Society, 7, 14 (August 1906), pp 606-615.

83. PA, HC/CL/JO/6/878, Session 1907, App. 24, p 15.

84. PA, HC/CL/JO/6/894, Session 1908, App. 51, p 33.

85. Hansard, Series 4, Volume 192, c 1084, (Seely), 16 July 1908.

86. PA, HC/CL/JO/6/912, Session 1909, App. 47, p 27. 
The petitioners requested the restrictive qualification on the membership of the Union parliament to "persons of European descent" be removed. A similar petition from the Reverend Elijah Makiwane and 2000 members of the Macfarlan Mission requested the removal of: "The discrimination against colour clauses for membership of parliament, allowing for possible disenfranchisement and from a part in the delimitation process". ${ }^{87}$ The British parliament showed no inclination to overturn decisions on the future constitution made at the South African National Convention and ratified by the four colonial parliaments. It is worth noting that political developments in South Africa attracted attention in India from where a petition by "Indian subjects of His Majesty the King Emperor living in the Presidency of Madras, and are greatly interested in the liberties, well-being, and prosperity of their fellow Indian subjects in the Transvaal", which noted the "increasing prejudice amongst the 'white' population in the South African colonies against Asiatics in general, and British Indians in particular". 88

No more petitions from South Africa were presented to the honourable House before the First World War. Nevertheless, in 1914, one was prepared by the newly formed South African Native National Congress, protesting at the 1913 Natives' Land Act and drawing attention to its negative consequences for the African population, which lacked an effective voice in the South African legislature. However, as a result of official obstruction and the outbreak of war, it was not presented to parliament. 89 Subsequently it was published in pamphlet form as an appeal to the people of Great Britain. ${ }^{90}$ This outcome was clearly a recognition that any intervention in South African internal affairs was now beyond the competence of the imperial parliament and a consequent narrowing of options open to African political organisations. ${ }^{91}$

\section{Comment}

The series of petitions from South Africans to the House of Commons in London between 1833 and 1914 presents one minor strand in the web of communications and flow of information within the British Empire. The strand spans the time from the first petition in 1833 which was concerned with white colonists wishing to retain slavery, to the last from African political movements and churches condemning the new South African constitution. This strand in the imperial web is of importance in demonstrating the longevity and adaptability of inherited practices even when the powers nominally vested in London had in reality passed to delegated local

87. PA, HC/CL/JO/6/912, Session 1909, App. 48, p 27.

88. PA, HC/CL/JO/6/912, Session 1909, App. 51, p 30.

89. H. Hughes, First President: A Life of John Dube, Founding President of the ANC (Jacana, Johannesburg, 2011), pp 182-189.

90. London School of Economics Library Archives, Special Collection, Pamphlets HD1(6)/D27. The Natives' Land Act of South Africa: An Appeal to the Members of the Imperial Parliament and Public of Great Britain (Edward Hughes, London, 1914).

91. P. Limb, “'No people can be expected to be loyal under such difficulties': Ambiguities and Identities of the early African National Congress Leaders in South Africa", Social Dynamics, 29, 1 (2003), pp 1-26. 
authorities. The nature of the petitions themselves changed through the period in line with changes noted elsewhere as personal grievances in large measure gave way to political advocacy and protest. Both motives tended to emphasise the differences which opened between the interests and outlook of an emerging colonial society and those in the imperial metropole. Personal grievances focused upon the perceived shortcomings of the imperial governments, notably their lack of support, false promises, misguided policies and procrastination; issues common to the entire history of petitioning.

Political advocacy in the form of protest and advice revolved around the development of new imperial policies, in order to influence the course of events rather than be passive bystanders. Only three issues excited a marked response from South African petitioners. The transportation crisis raised the issue of the future character of society in the country as a convict colony. The successful opposition to imperial policy, created a sense of solidarity in white society. The prompting of the introduction of representative government, in line with the North American and Australasian colonies, similarly departed from a centralised imperial administration and the emergence of self-governing states, controlled by the settler communities. However, the third major petitioning movement was backward looking concerned with the preservation of the status of the Church of England in the light of the disestablishment debates in Ireland and other colonies. A late development was the largely unsuccessful initiation of petitioning by the indigenous African population to draw attention to constitutional developments in the country which negatively impacted upon them, notably access to the local franchise. In this process loyalty to the imperial link, particularly the Crown, was stressed as a means of restraining the settler communities, which controlled the local legislatures, from further diminishing the legal status of the African and coloured population. The use of political petitioning followed the precedent demonstrated by the indigenous inhabitants of other colonial dependencies, notably India. In all cases petitions included substantial amounts of supporting information to advance the case presented. This was of value to the authorities in the tasks of adjudication and administration and remains as an insight into the concerns of the age raised by specific groups and individuals.

The successful characteristics of political advocacy and protest included mass petitioning through either large numbers of signatures or large numbers of petitions. Neither option was open to South Africans as the population of the country was small and there were rarely more than a few petitions presented on any issue, enabling the House of Commons to ignore them, when confronted with more immediate problems. Petitioning the honourable House was though a link of final recourse, when all else had failed, symbolising the continued unity of the British Empire in an era when local political processes were evolving rapidly. Colonial political advancement essentially made the strand obsolete, as local legislatures assumed increasing control over their own affairs, and the imperial parliament became unwilling and ultimately unable to intervene. It is worth observing that the right to petition parliament was retained in local constitutions, based on the Westminster model, and has remained a vital element in the governmental process as a direct link between rulers and ruled. 


\section{REFERENCES}

Abraham, S., "Formal Writing, Questionnaires and Petitions: Colonial Governance and Law in early Malabar, 1792-1810", Indian Historical Review, 40, 2 (2013).

Akurang-Parry, K.O., 'A smattering of education' and Petitions as Sources: A Study of African Slaveholders' Responses to Abolition in the Gold Coast Colony, 18741875", History in Africa, 37 (2000).

Bell, P.M.H., Disestablishment in Ireland and Wales (S.P.C.K., London, 1969).

Blaine, M.S., "The Power of Petitions: Women and the New Hampshire Provincial Government, 1695-1770", International Review of Social History, 46, 9 (2001).

Bradley, J.E., "Parliament, Print Culture and Petitioning in late Eighteenth-century England", Parliamentary History, 26, 1 (2007).

Brand, P., "Petitions and Parliament in the Reign of Edward I", Parliamentary History, 23, 1 (2004).

Christopher, A.J., "The Religious Question in the United Kingdom Census, 1801-2011", Journal of Ecclesiastical History, 65, 3 (2014).

Corbett, N., "Parliamentary Petitions: An Untapped Library Resource", Australian Library Journal, 60, 3 (2011).

Dodd, G., Justice and Grace: Private Petitioning and the English Parliament in the late Middle Ages (Oxford University Press, Oxford, 2007).

Drescher, S., Capitalism and Antislavery: British Mobilization in Comparative Perspective (Oxford University Press, Oxford, 1984).

Drescher, S., "Public Opinion and Parliament in the Abolition of the British Slave Trade", Parliamentary History, 26, 1 (2007).

Ellingford, K., "The Purpose, Practice and Effects of Petitioning the Victorian Parliament", Australasian Parliamentary Review, 23, 2 (2008).

Fraser, P., "Public Petitioning and Parliament before 1832", History, 26, 158 (1961).

Greenaway, J., Drink and British Politics since 1830: A Study in Policy Making (Palgrave Macmillan, Basingstoke, 2003).

Handley, R., "Public Order, Petitioning and Freedom of Assembly", Journal of Legal History, 7, 2 (1986).

Hattersley, A.F., The Convict Crisis and the Growth of Unity: Resistance to Transportation in South Africa and Australia, 1848-1853 (University of Natal Press, Pietermaritzburg, 1965).

Heerma van Voss, L., "Petitions in Social History: Introduction”, International Review of Social History, 46, 9 (2001).

Hirst, D., "Making Contact: Petitions and the English Republic", Journal of British Studies, 45, 1 (2006).

Hough, R., "Do Legislative Petitions Enhance the Relationship between Parliament and Citizen?" Journal of Legislative Systems, 18, 3-4 (2012).

Houston, R.A., Peasant Petitions: Social Relations and Economic Life on Landed Estates (Palgrave Macmillan, Basingstoke, 2014).

Hughes, H., First President: A Life of John Dube, Founding President of the ANC (Jacana, Johannesburg, 2011).

Jack, M., Erskine May's Treatise on the Law, Privileges and Usage of Parliament (NexisLexis, London, 2011). 
Johnson, J.K., '“Claims of equity and justice': Petitions and Petitioners in Upper Canada 1815-1840", Histoire Sociale/Social History, 28, 55 (1995).

Judge, D., "Public Petitions and the House of Commons", Parliamentary Affairs, 31, 4 (1978).

Kapteijns, L. and Spaulding, J., "Women of the Zar and Middle-class Sensibilities in Colonial Aden, 1923-1932", Sudanic Africa, 5 (1994).

Karis, T. and Carter, G.M. (eds), From Protest to Challenge: A Documentary History of African Politics in South Africa, Volume 1, Protest and Hope, 1882-1934 (Hoover Institution Press, Stanford: CA, 1972).

Korieh, C.J., "'May it please your Honor': Letters of Petition as Historical Evidence in an African Colonial Context", History in Africa, 37 (2010).

Kumin, B. and Würgler, A., "Petitions, Gravamina and the early Modern States: Local Influence on Central Legislation in England and Germany (Hesse)", Parliaments, Estates and Representation, 17 (1997).

Kuper, L., "African Nationalism in South Africa, 1910-1964", in Wilson, M. and Thompson, L.M. (eds), The Oxford History of South Africa, II, 1870-1966 (Clarendon Press, Oxford, 1971).

Kynoch, G., 'YYour petitioners are in mortal terror': The Violent World of Chinese Mineworkers in South Africa, 1904-1910", Journal of Southern African Studies, 31, 3 (2005).

Laidlaw, Z., Colonial Connections: Patronage, the Information Revolution and Colonial Government (Manchester University Press, Manchester, 2005).

Lambert, D., "The Counter-revolutionary Atlantic: White West Indian Petitions and Proslavery Networks", Social and Cultural Geography, 6, 3 (2005).

Lester, A., "Imperial Circuits and Networks: Geographies of the British Empire", History Compass, 4, 1 (2006).

Lester, A., Imperial Identities: Creating Identities in Nineteenth Century South Africa and Britain (Routledge, London, 2001).

Leys, C., "Petitioning in the 19th and 20th Centuries", Political Studies, 3, 1 (1955).

Limb, P., "'No people can be expected to be loyal under such difficulties': Ambiguities and Identities of early African National Congress Leaders", Social Dynamics, 29, 1 (2003).

Lunn, K. and Day, A., "Deference and Defiance: The Changing Nature of Petitioning in British Naval Dockyards", International Review of Social History, 46, 9 (2001).

Matthew, E., "Law and Religion in South Africa: An Anglican Perspective", Dutch Reformed Theological Journal, 54, 4 (2013).

Magee, G.B. and Thompson, A.S., Empire and Globalisation: Networks of People, Goods and Capital in the British World c1850-1914 (Cambridge University Press, Cambridge, 2010).

McCracken, J.L., The Cape Parliament 1854-1910 (Clarendon Press, Oxford, 1967).

Nicholls, D., "Addressing God as Ruler: Prayer and Petition", British Journal of Sociology, 44, 1 (1993).

Pepin, G., "Petitions from Gascony: Testimonies of a Special Relationship", in Ormrod, W.M, Dodd, G. and Musson, A. (eds), Medieval Petitions: Grace and Grievance (York Medieval Press, Woodbridge, 2007).

Pickering, P.A., '“And Your Petitioners \&c.': Chartist Petitioning in Popular Politics 1838-48”, English Historical Review, 116, 466 (2001). 
Reed, C.V., Royal Tourists, Colonial Subjects and the Making of a British World, 18601911 (Manchester University Press, Manchester, 2016).

Robertson, J.R., Petitions of the early Inhabitants of Kentucky to the General Assembly of Virginia 1769 to 1792 (Genealogical Publishing, Baltimore: MD, 1998).

Siddiqi, M., The British Historical Context and Petitioning in Colonial India (Aakar Books, New Delhi, 2005).

Swarnalatha, P., "Revolt, Testimony, Petition: Artisanal Protests in Colonial Andhra", International Review of Social History, 46, 9 (2001).

Thompson, A., "The Languages of Loyalism in South Africa, c1870-1939", English Historical Review 118, 447 (2003).

Vernet, J., "Petitions from the Peripheries of Empire: Louisiana and Quebec", American Review of Canadian Studies, 38, 4 (2008).

Wolf, E., "The Authorship of the 1774 Address to the King Restudied", William and Mary Quarterly, 22, 2 (1965).

Würgler, A., "Voices from among the 'silent masses': Humble Petitions and Social Conflicts in early Modern Central Europe", International Review of Social History, 46, 9 (2001).

Zaeske, S., "Signatures of Citizenship: The Rhetoric of Women's Antislavery Petitions", Quarterly Journal of Speech, 88, 2 (2002).

Zaret, D., Origins of Democratic Culture: Printing, Petitions and the Public Sphere in early Modern England (Princeton University Press, Princeton: NJ, 2000). 